\title{
Applying Benford's Law to Detect Accounting Data Manipulation in the Banking Industry
}

\author{
Theoharry Grammatikos ${ }^{1}$ • Nikolaos I. Papanikolaou ${ }^{2}$
}

Received: 7 November 2018 / Revised: 10 January 2020 / Accepted: 19 February 2020 /

Published online: 9 May 2020

(C) The Author(s) 2020

\begin{abstract}
We utilise Benford's Law, which predicts the frequencies in different digits in data, to test if balance sheet and income statement data used to assess bank soundness were manipulated prior to, and also during, the global financial crisis. We find that banks adjust loan loss provisions to manipulate earnings and income upwards. Distressed institutions that have stronger incentives to conceal their financial difficulties also manipulate loan loss allowances and non-performing loans downwards. Moreover, manipulation is magnified during the crisis and expands to encompass regulatory capital.
\end{abstract}

Keywords financial crisis · banks · Benford's Law $\cdot$ financial accounting $\cdot$ data manipulation

JEL Code $\mathrm{G} 01 \cdot \mathrm{G} 21 \cdot \mathrm{M} 41 \cdot \mathrm{M} 48$

\section{Introduction}

The 2007-9 global financial crisis brought to light several cases of financial accounting misreporting in the banking industry. The U.S. Securities and Exchange Commission (SEC)'s push to step up its policing of accounting fraud led to a surge of cases and investigations. For example, the First National Community Bancorp's methodology for determining the amount of impairment on securities was found to not comply with the Generally Accepted Accounting

Electronic supplementary material The online version of this article (https://doi.org/10.1007/s10693-02000334-9) contains supplementary material, which is available to authorized users.

Nikolaos I. Papanikolaou

npapanikolaou@bournemouth.ac.uk

Theoharry Grammatikos

theoharry.grammatikos@uni.lu

1 Luxembourg School of Finance, University of Luxembourg, Esch-sur-Alzette, Luxembourg

2 Department of Accounting, Finance and Economics, Bournemouth University, Poole, UK 
Principles (GAAP), and, hence, the bank understated losses in 2009 and 2010 (Securities and Exchange Commission (SEC) 2015). Similarly, Bank of America Corp. failed to deduct certain realised losses when it calculated and reported its regulatory capital, meaning that capital was overstated in its SEC filings from 2009 to 2013 (Securities and Exchange Commission (SEC) 2014). In the same vein, Fifth Third Bancorp. failed to record substantial losses during the crisis by not properly considering a portion of its non-performing loan portfolio (Securities and Exchange Commission (SEC) 2013).

Auditors failed in several instances to raise the alarm to the authorities for considerable discrepancies in the books of banks. The Federal Deposit Insurance Corporation (FDIC) sued PricewaterhouseCoopers $(\mathrm{PwC})$ for $\$ 1$ billion for not detecting a massive accounting fraud that brought down Colonial Bank in 2009. PwC was blamed for missing huge holes in Colonial's balance sheet without ever detecting the multibillion-dollar fraud at Taylor Bean \& Whitaker Mortgage Corp., which was Colonial's largest client. Furthermore, two KPMG auditors received suspensions for failing to scrutinise loan loss reserves at TierOne Bank, which also went bankrupt during the crisis. Along the same lines, just eight months prior to the demise of Lehman Brothers, Ernst and Young's auditors remained silent about the repurchase transactions that significantly disguised the bank's leverage.

This paper evaluates the financial statements of U.S. banks by employing a mathematical law which was established by Frank Benford (Benford 1938) to detect data manipulation. If an accounting figure is manipulated upwards to increase the digit in the first position by one, a higher than the anticipated proportion of low numbers and a lower than expected frequency of high numbers will occur in the second position. This describes an uncommon digital pattern that violates Benford's Law and indicates an upward data manipulation; if the converse holds true, then data are subjected to downward manipulation. An upward manipulation pattern suggests that when an accounting figure starts with either the digit eight or nine it is more likely to be rounded up to a figure which has a one as the first digit. In the context of downward manipulation, the value of an accounting figure is lowered when its first digit is one to a figure which starts with the digit nine.

Despite substantial progress in the areas of financial misreporting and accounting fraud, existing methods and metrics have several deficiencies that limit their usefulness. The use of Benford's Law is deemed as being superior to other traditional approaches as it overcomes some of the key concerns surrounding these approaches. Prior work has utilised Benford's Law to identify accounting fraud and data manipulation in corporate firms (e.g., Alali and Romero 2013). Prior literature has also linked the use of Benford's Law in the realm of financial audits (Durtschi et al. 2004), taxes (e.g., Nigrini 1996), macroeconomic indicators (e.g., Gonzales-Garcia and Pastor 2009), and interest rates (e.g., Ashton and Hudson 2008). However, no paper has ever applied the Law to identify irregularities in financial reporting in the banking industry, making this a key innovation of our study.

Banks are special entities from various perspectives and, as such, their accounting books require special attention. The banking sector is one of the most heavily regulated sectors in the economy and a key regulatory measure is a capital adequacy requirement that provides loss absorbency. Troubled banks have incentives to overstate equity and regulatory capital, particularly during economic downturns (e.g., Vyas 2011; Huizinga and Laeven 2012). Furthermore, since banks' capital requirements are linked to the riskiness of their portfolios, bank accountants face incentives to overstate the quality of assets and understate the relevant risks and potential losses. Banks' high leverage provides additional incentives to remain undercapitalised, since the benefits of issuing new equity primarily accrue to creditors, and also to make excessively 
risky investment decisions (Jensen and Meckling 1976). These moral hazard incentives may be exacerbated for larger banks that expect to be bailed out when insolvent. Moreover, banks are inherently opaque (Morgan 2002; Flannery et al. 2013) in lending decisions that are based on private information about borrowers and projects that is not available to those outside the bank (e.g., Diamond 1984). Additionally, in contrast to corporate firms, banks are engaged in a broad array of trading activities that produce non-interest income and which makes banks relatively more complex (Morgan 2002; Laeven 2013). In this context, accruals for banks reflect different considerations than those that drive accruals for corporate firms (Cohen et al. 2014). Lastly, since banks finance illiquid loans with liquid deposits, they have incentives to show to depositors and to other creditors that their portfolios are highly liquid.

To capture the complexity in the functions that banks perform as presented above and the likely manipulation in their relevant accounting figures, we shed light on a wide array of balance sheet and income statement variables used by U.S. authorities to monitor the performance and soundness of banks. We analyse the components of the CAMELS rating system that capture capital adequacy, asset quality, earnings strength, and the level of liquidity, which managers have inherent incentives to manipulate. This more comprehensive analysis distinguishes our paper from the bulk of the Benford's Law literature that focuses on the manipulation of earnings and earnings-related figures of corporate firms (e.g., Carslaw 1988; Thomas 1989; Niskanen and Keloharju 2000; Van Caneghem 2002). The paper also differs from the banking literature that explores how managers use accounting discretion to manage earnings by employing various loan loss provisioning discretion models (e.g., Ahmed et al. 1999; Beatty et al. 2002; Cohen et al. 2014). ${ }^{1}$

Poor accounting data quality and weak disclosure practices combined with possible data manipulation in the banking sector have contributed to the propagation and the prolongation of the recent crisis and can possibly plant the seeds for the next financial turmoil. That said, an additional innovation of our paper is that we test for data manipulation prior to the outbreak of the crisis as well as during the crisis. The crisis offers an excellent research environment that enables us to turn the spotlight on any discrepancies in financial reporting across banks in different financial conditions and to explore how Benford's Law can be used to document those discrepancies.

We report several interesting results, which are all robust to a number of sensitivity and placebo tests. Banks utilise loan loss provisions to manipulate earnings and interest income upwards throughout the two examined periods regardless of their level of soundness. In the case of bailed-out banks, non-interest income is also found to be manipulated upwards in both periods. Together with loan loss provisions, failed and bailed-out banks resort to a downward manipulation of their allowance for loan losses and non-performing loans. Furthermore, manipulation is found to be more prevalent in distressed banks, which have stronger incentives to conceal their financial difficulties. Importantly, manipulation is both magnified during the crisis period and also expanded to affect regulatory capital. Overall, banks utilise data manipulation to disclose an artificially improved picture of their performance.

The rest of the paper proceeds as follows. Section 2 describes the theoretical underpinnings of Benford's Law, presents the relevant literature, and clarifies how Benford's Law addresses the limitations of some previous methods. The data and the tools we employ in our empirical analysis are described in Section 3. Section 4 presents our main empirical results and Section 5 performs a series of robustness checks, and then Section 6 concludes.

\footnotetext{
${ }^{1}$ Beatty and Liao (2014) offer a comprehensive review of the various models used in this strand of literature.
} 


\section{Benford's Law}

\subsection{Background and Theoretical Underpinnings}

Newcomb (1881) noted that the initial pages of a book of logarithmic tables were more worn than latter pages; similarly, numbers with the first digit of 1 were observed more often than those starting with 2, 3 and so on. On that basis, he developed a set of mathematical theorems to show that low numbers possess a larger probability of appearing in the first two digital positions within a number compared to high numbers (Nigrini 2012).

Almost fifty years later, Benford (1938) focused on the expected distribution of digits in data sets which are not contrived by man or machine. He formulated the expected frequencies for the first and the second positions in a number together with their combinations and found that, when the data are ranked from smallest to largest, they form a geometric sequence. The leading digits follow a logarithmic weak monotonic distribution, which is described by the following expressions:

$$
f(i)=\log _{10}\left(1+i^{-1}\right) \text {, }
$$

and

$$
\sum_{i=0}^{9} f(i)=1
$$

where $f(i)$ stands for the frequency of digit $i$ implied by Benford's Law being the first or other leading digit; $i=0,1,2, \ldots, 9$; and $\log _{10}$ is the base 10 logarithm. Apparently, the first digit cannot take the value of 0 , unless the number under scrutiny is a decimal number. As shown in Table 1, digit 1 possesses a $30.10 \%$ likelihood of appearing in the first digital place within a number, while digit 9 has only a $4.58 \%$ likelihood of occurring in the first place. More generally, digit 1 occurs more often than any other digit in the first position of a number; the frequency of the remaining digits decreases with respect to the value of the digits.

The expected digital frequencies for the first and the second places based on Benford's distribution are graphically presented in Fig. 1.

Benford's distribution of digits is an empirically observable phenomenon. If distributions are selected at random and random samples are taken from each of these distributions, then the

\begin{tabular}{|c|c|c|c|c|}
\hline Digit & 1st place & 2nd place & 3rd place & 4th place \\
\hline 0 & & .1197 & .1018 & .1002 \\
\hline 1 & .3010 & .1139 & .1014 & .1001 \\
\hline 2 & .1761 & .1088 & .1010 & .1001 \\
\hline 3 & .1249 & .1043 & .1006 & .1001 \\
\hline 4 & .0969 & .1003 & .1002 & .1000 \\
\hline 5 & .0792 & .0967 & .0998 & .0999 \\
\hline 6 & .0670 & .0934 & .0994 & .0999 \\
\hline 7 & .0580 & .0904 & .0990 & .0999 \\
\hline 8 & .0512 & .0876 & .0986 & .0999 \\
\hline 9 & .0458 & .0850 & .0983 & .0998 \\
\hline
\end{tabular}

Table 1 Benford's expected digital frequencies

This Table presents the expected frequencies for digits 0 through 9 in each of the first four places in any number based on Benford's distribution 


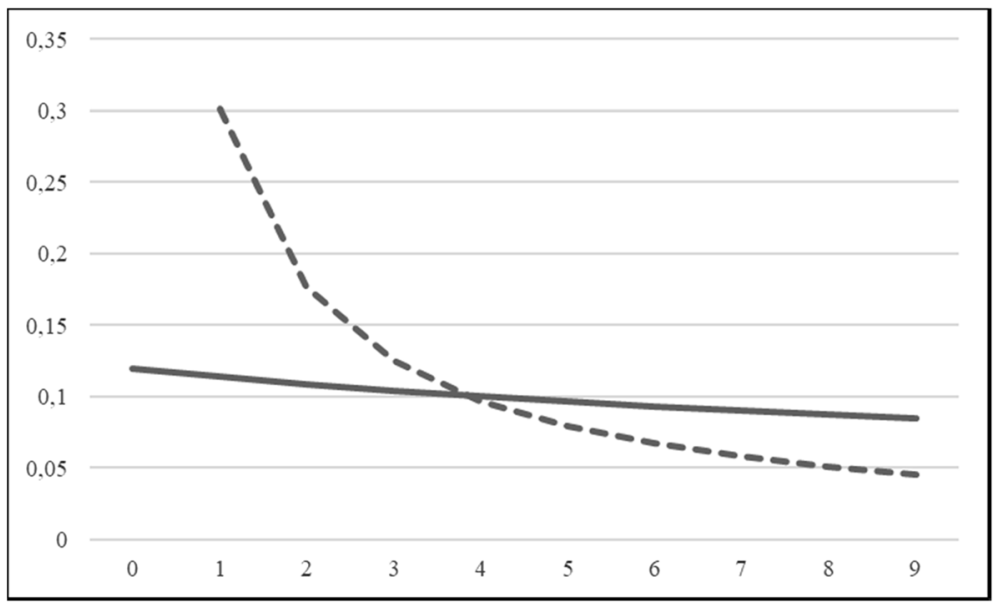

Fig. 1 Benford's expected frequencies for the first and second digits. This Figure contains a graphical representation of the expected frequencies for the first digit (dashed line) and for the second digit (solid line) based on Benford's distribution. The values on the vertical axis are the distribution probabilities of digit $i$ as shown on the horizontal axis, where $i=0,1,2, \ldots, 9$

significant digital frequencies of the combined samplings are expected to converge to Benford's distribution, even though the individual distributions may not closely follow the Law. In the context of our research, this means that if the digital frequency in the bank accounting data departs from the expectations of Benford's Law, then data is likely to have been manipulated.

\subsection{Related Literature}

Prior literature primarily focuses on the compliance of earnings and earnings-related figures with Benford's Law in the corporate sector. Carslaw (1988) uses a sample of 220 firms in New Zealand to test whether managers tend to round income upwards when this is below some psychological threshold value. An abnormally high frequency of digit zero and an unusually low occurrence of digit nine are documented in the second position of the examined figures, providing support to the relevant hypothesis. In a similar vein, Thomas (1989) reports similar, though considerably smaller, deviations from the expected frequencies in the quarterly earnings of U.S. firms, whilst a reverse pattern with fewer zeros and more nines is reported for losses.

Tilden and Janes (2012) show that corporate accounting data conform to the Law under normal economic and financial conditions. However, some figures like the allowance for doubtful accounts and the net income fail to conform in periods surrounding recessions. Alali and Romero (2013) apply the Law on the books of a sample of U.S. corporate firms to detect any digital frequency discrepancies in their revenues, expenses, assets, and liabilities. The study of Lin and Wu (2014) uses the Law to capture earnings manipulation in the Taiwanese and the U.S. corporate sectors, whereas that of Lin et al. (2018) is solely focused on earnings manipulation in Taiwanese firms. Further research on earnings manipulation based on Benford's Law has been conducted by Niskanen and Keloharju (2000), Van Caneghem (2002), and Skousen et al. (2004) for the Finnish, U.K., and Japanese corporate companies, respectively. 
In a different context, Nigrini (1996) uses the Law to show that taxpayers lean towards understating real taxable income. Similarly, Nigrini and Mittermaier (1997) detect fraudulent data in tax payments and accounting statements. Durtschi et al. (2004) provide further support to the importance of the Law in helping auditors to increase their ability to detect fraudulent practices. ${ }^{2}$

\subsection{Advantages}

Most existing models for detecting accounting manipulation (Healy (1985) model; Jones model (Jones 1991); modified Jones model (Dechow et al. 1995; Kothari et al. 2005); McNichols (2000) model; Dechow and Dichev (2002) model) are designed to detect earnings management by partitioning accruals into their discretionary and non-discretionary components (Dechow et al. 2012). They focus on the discretion of managers that fall within the relevant accounting standards. Furthermore, as Dechow et al. (2012) point out, these models are implemented through the use of a firm-specific estimation period during which no systematic earnings management is assumed. Unlike Benford's Law, they cannot capture systematic fraud or accounting data manipulation.

Many models rely on working capital accruals, which are, however, less meaningful for banks. Therefore, studies (e.g., Healy 1985; Dechow and Dichev 2002; Dechow et al. 2012) exclude the latter institutions from their analysis. Moreover, they typically analyse firmspecific characteristics to estimate the managed portion of reported earnings, which may incidentally capture the individual characteristics of the examined entities beyond reporting the quality of the accounting data. In contrast, the distribution of the first digits upon which Benford's Law relies is independent of firm-level characteristics (Dechow et al. 2010; Amiram et al. 2015). Benford's Law hinges upon the distributional properties of the reported accounting figures and, as such, it measures the quality of the data directly, rather than some variables correlated with the examined figures (Amiram et al. 2015). This is crucial in the context of our research as banks follow different business models.

Benford's distribution is very simple to calculate, is scale-independent and fits every currency (Amiram et al. 2015). Also, in contrast to accrual models, it does not require aggregated, large time series, or cross-sectional data (Dechow et al. 1995; Dechow et al. 2011). Additionally, Benford's Law constitutes a non-econometric approach in that it does not rely on the estimation of a model, so that statistical inference cannot be biased by unobserved characteristics, omitted variables, or any changes in the underlying model parameters that cause the estimated coefficients to deviate from the actual ones (Kothari et al. 2005; Dechow et al. 2010). ${ }^{3}$ Benford's Law neither requires forward-looking information such as future realisations of cash flows (e.g., Dechow and Dichev 2002), nor relies on returns or price information that may give birth to selection bias (Amiram et al. 2015). Also, if realisations of forward-looking information are correlated with current information, then their use may create inference bias (Amiram et al. 2015).

\footnotetext{
${ }^{2}$ The Law is also utilised in testing the quality of macroeconomic data (Nye and Moul 2007; Gonzales-Garcia and Pastor 2009; Brahler et al. 2011; Michalski and Stoltz 2012). Other applications of Benford's Law in the broader economic literature are those of Diekmann (2007), Hales et al. (2008), Judge and Schechter (2009), Ashton and Hudson (2008), and Abrantes-Metz et al. (2011).

${ }^{3}$ Performance matching procedures have been adopted to alleviate misspecification (e.g., Kothari et al. 2005), but cause substantial reductions in test power and are only effective when the matching procedure employs the relevant omitted variable. Furthermore, in accrual-based techniques there may be measurement errors in estimating accruals (Hribar and Collins 2002).
} 
Other studies develop composite indices instead of employing accrual-based models to estimate earnings manipulation. Beneish's M-Score (Beneish 1999; Beneish et al. 2013) is constructed as a linear combination of firm-level performance variables such as gross margin and sales growth. As such, it is difficult to conclude about errors that are separate from firm performance (Amiram et al. 2015). Importantly, because banks have highly leveraged capital structures, the M-score, which keys in on leverage, is not applicable to banks and, hence, removed from the analyses of Beneish (1999) and Beneish et al. (2013). Importantly, unlike Beneish's M-Score, Benford's Law does not require the ex ante identification of managerial incentives to capture data manipulation. Dechow et al. (2011) develop the F-Score, which is used to estimate the likelihood of earnings misstatement. However, it cannot be applied to banks due to many accrual-related variables used in its construction.

\section{Empirical Analysis}

\subsection{Data Period}

We utilise quarterly data from the first quarter of 2003 (2003q1) to the last quarter of 2012 (2012q4) when the banking crisis in the U.S. came to a halt in that the number of failed or bailed out banks shrank significantly in 2013 and thereafter. The data period is divided into two periods. The former period includes the quarters prior to the outbreak of the crisis (2003q1-2007q3), that is before September 2007 when the TED spread widened to almost 200 basis points relative to its historically stable range of $10-50$ basis points. ${ }^{4}$ This period follows the development and the implementation of the Sarbanes-Oxley Act in mid-2002 which enhanced scrutiny of financial reporting in the U.S.. The latter period extends from $2007 q 4$ to $2012 q 4$ and encompasses the crisis quarters in which financial turbulence, uncertainty, and distress prevailed in the economy. This was the period when several financial reporting misstatements and frauds in the banking industry occurred (see, e.g., Securities and Exchange Commission (SEC) 2013, 2014, 2015).

\subsection{Data Set}

We focus on the U.S. commercial and savings banking institutions that file a Report on Condition and Income (also known as a Call Report). Sample banks are classified into distressed and non-distressed banks. We define distressed banks as those that either filed for bankruptcy or were bailed out during the crisis. For the period starting from $2007 \mathrm{q} 4$ and extending to 2012q4, there were recorded 449 bank failures (396 and 53 failures of commercial and savings banks, respectively) based on FDIC data. To construct the sample of bailedout banks, we identify all banks that received financial aid via the Capital Purchase Program (CPP) of the Troubled Asset Relief Program (TARP). The TARP/CPP was the largest U.S. government bailout programme in history. It was established in 2008 and authorised the U.S. Treasury to inject capital into the banking system by purchasing up to $\$ 250$ billion of preferred

\footnotetext{
${ }^{4}$ The TED spread shows the difference between the yield on the three-month LIBOR and the yield on the threemonth U.S. Treasury bills and is one of the most widely-used indicators of credit risk.
} 
stocks and equity warrants from the undercapitalised banks. Based on U.S. Treasury data, we identify 731 banks that received TARP/CPP funding via their parent holding companies (HCs). ${ }^{5}$ We add to this the 93 banks which are not linked to some HC to construct the final sample of 824 bailed-out banks. As regards the group of non-distressed banks, this is composed of the institutions that stayed afloat as going concern entities in that they neither failed, nor received a TARP/CPP assistance, nor merged with or acquired by some other institution throughout the entire sample period. Overall, we identify 6302 non-distressed banks.

\subsection{Variables}

The bank accounting data that we test is based on that used by the Uniform Financial Rating System, known as CAMELS. ${ }^{6}$ CAMELS are not publicly available and cannot be exactly replicated with public information, so we follow the literature (see, e.g., Stojanovic et al. 2008; Duchin and Sosyura 2012) to construct a set of accounting variables that reflect Capital adequacy, Asset quality, Earnings strength, and Liquidity. We do not account for Sensitivity to market risk because this component is captured by market data, nor do we consider Management expertise because supervisors likely rate this component on qualitative, subjective factors. ${ }^{7}$

We measure capital adequacy by using the core regulatory capital (TIER 1); asset quality is measured by loan loss provisions ( $L L P)$; earnings strength is based on total interest income (INTINC), and total non-interest income (NINTIC); and liquidity is captured by cash and balances due from depository institutions $(\mathrm{CASH})$. The construction of variables relies on quarterly data collected from Call Reports as found in the website of the Federal Reserve Bank of Chicago and that of the Federal Financial Institutions Examination Council (FFIEC) Central Data Repository's Public Data Distribution. All variables and their data sources are described in Table 2.

\subsection{Digital Analysis}

Seminal studies (e.g., Carslaw 1988; Thomas 1989) as well as more recent studies (Niskanen and Keloharju 2000; Van Caneghem 2002) on manipulation based on Benford's Law primarily focus on the second-from-the-left position of the examined accounting figures. The main reason for this is that manipulation can be independent of the first position. If manipulation is detected in the second position, then its pattern can be identified by applying the Law to the first position.

We compare the actual with the expected frequencies predicted by Benford's Law of the digits zero through nine appearing in the second position of the variables of interest. If a variable is manipulated upwards to increase the digit in the first position by one, a higher than

\footnotetext{
${ }^{5}$ See: https://www.treasury.gov/initiatives/financial-stability/reports/Pages/TARP-Investment-ProgramTransaction-Reports.aspx

${ }^{6}$ The CAMEL rating system was introduced by the U.S. authorities in November 1979 to evaluate the individual performance and soundness of banks and to monitor the conditions in the industry. CAMEL is a vector of five different yet interrelated measures capturing Capital adequacy, Asset quality, Management expertise, Earnings strength, and Liquidity. In 1996, CAMEL evolved into CAMELS, with the addition of a sixth component ('S') that summarises the Sensitivity to market risk.

${ }^{7}$ We thank George Pennacchi and Franco Fiordelisi for their insightful comments and suggestions.
} 
Table 2 Bank accounting variables and data sources

\begin{tabular}{|c|c|c|c|}
\hline CAMEL components & Variables & Abbreviation & Data Source \\
\hline \multirow{2}{*}{ Capital adequacy } & Core regulatory capital & TIER1 & \multirow{10}{*}{ Call reports } \\
\hline & Book equity capital & EQUITY & \\
\hline \multirow{3}{*}{ Asset quality } & Loan loss provisions & $L L P$ & \\
\hline & Allowances for loan losses & $A L L O W$ & \\
\hline & Non-performing loans & $N P L$ & \\
\hline \multirow{3}{*}{ Earnings strength } & Total interest income & INTINC & \\
\hline & Total non-interest income & NINTINC & \\
\hline & Total earning assets & EARNAS & \\
\hline \multirow[b]{2}{*}{ Liquidity } & $\begin{array}{l}\text { Cash and balances due from } \\
\text { depository institutions }\end{array}$ & $\mathrm{CASH}$ & \\
\hline & $\begin{array}{l}\text { Federal funds purchased } \\
\text { and securities sold under } \\
\text { agreements to repurchase }\end{array}$ & REPOS & \\
\hline
\end{tabular}

This Table presents all the variables we employ in our empirical analysis. The abbreviation of each variable and the source we use to collect the relevant accounting data are also reported in the last two columns

the anticipated proportion of low numbers (mostly zeros or ones) and a lower than expected frequency of high numbers (mostly nines or eights) will occur in the second position. This describes an uncommon digital pattern that violates Benford's Law and indicates an upward data manipulation. If the reverse pattern is observed, i.e., more high digits and fewer low digits than expected appear in the second position, then data are suspect for a downward manipulation. A positive deviation implies that the actual proportions exceed the expected ones, while a negative deviation shows that the converse holds true.

Following the literature (e.g., Thomas 1989; Nigrini 1996; Durtschi et al. 2004), we resort to the normally distributed $z$-statistic to examine the statistical significance of the deviations in the actual and the expected proportions:

$$
z_{i}=\frac{\left|p_{0}-p_{i}\right|-\left(\frac{1}{2 n}\right)}{s_{i}},
$$

where $z_{i}$ is the $z$-statistic for digit $i$ where $i=0,1,2, \ldots, 9 ; p_{0}$ denotes the actual (observed) proportion; $p_{i}$ is the expected proportion based on Benford's Law; $n$ is the number of observations of the examined variable; the term $\frac{1}{2 n}$ is the Yates' continuity correction term that is applied only when its value is smaller than that of $\left|p_{0}-p_{i}\right|$ to bring normal and binomial probability curves into close agreement; and $s_{i}$ is the standard deviation of digit $i$ given by:

$$
s_{i}=\left[p_{i}\left(\left(1-p_{i}\right) / n\right)\right]^{1 / 2}
$$

The $z$-statistic tests the null hypothesis that the actual proportion does not statistically differ from the expected proportion based on Benford's Law. As the difference between $p_{0}$ and $p_{i}$ increases in Eq. (3), the $z$-statistic becomes larger. A $z$-statistic of: 2.57 indicates a $p$ value of $0.01 ; 1.96$ indicates a $p$ value of 0.05 ; and 1.64 suggests a $p$ value of 0.10 .

An extension of the $z$-statistic that tests one digit at a time is the chi-square test, which is a 'goodness-of-fit' test conducted over all nine digits of the second position of the variables under scrutiny (see, e.g., Carslaw 1988; Thomas 1989; Durtschi et al. 2004). The chi-square test explores whether the observed distribution significantly differs from the expected 
distribution. If the chi-square test rejects the null hypothesis that the probability of all digits conforms to the expected distribution under the Law, then this is a strong signal for data manipulation. The value of chi-square is determined as follows:

$$
\chi_{(9)}^{2}=n \sum_{i=0}^{9} \frac{\left(\widehat{\theta}_{i}-f(i)\right)^{2}}{f(i)},
$$

where $\widehat{\theta}_{i}$ is the observed frequency of digit $i$; $(i)$ stands for the frequency of digit $i$ implied by the Law as noted under Eqs. (1) and (2); $n$ is the number of observations for the examined variable. The conformity of the entire distribution is tested, implying that the results are summed up for all digits $i=0,1,2, \ldots, 9$. As we focus on the second position, we have nine degrees of freedom, i.e., $\chi_{(9)}^{2}$. The $10 \%, 5 \%$, and $1 \%$ critical values for $\chi_{(9)}^{2}$ are $14.68,16.92$, and 21.97 , respectively.

The digit-by-digit analysis based on the $z$-statistic and the variable-by-variable chi-square test are complementary. The former has a discriminatory character in that it draws attention to certain digits with peaks. It is utilised to reduce the probability of Type I and II Errors. A Type I Error occurs when a variable is not manipulated, but it is signaled as it underlies a human intervention. A Type II Error occurs when a variable that actually underlies some portion of human intervention is signaled as not being manipulated. The latter analysis investigates whether the behaviour of a variable as a whole warrants further examination.

\section{Results}

The results of the digital analysis for the second position based on the $z$-statistic and the chisquare tests are presented in Tables 3 and 4 for the pre- and the crisis periods, respectively. For ease of comprehension, we provide graphical representations of the results in Figs. 2 and 3.

\subsection{The Pre-Crisis Period}

The actual proportion of zeros appearing in the second position of interest income (INTINC) for non-distressed banks exceeds the expected proportion by $5.56 \%$. The reported deviation is statistically significant at the $5 \%$ level. Similarly, the actual proportion of ones significantly exceeds the expected proportion by $3.95 \%$. If we apply the same procedure to the remaining numbers (i.e., two through nine) appearing in the second position of INTINC, we will observe that eights and nines produce actual proportions which are significantly (at 5\%) lower than the anticipated proportions. More specifically, deviations are equal to $-2.56 \%$ and $-7.18 \%$, respectively. The chi-square test suggests a rejection of the hypothesis that the INTINC data are generated by Benford's distribution. Overall, results demonstrate a clear indication of data manipulation: banks which remained afloat, appeared to round INTINC upwards in the years preceding the crisis to signal a higher profitability and more robust interest-bearing activities. This group of banks also manipulated loan loss provisions downwards as shown in Fig. 2 (Panel B), confirming earlier research (e.g., Greenawalt and Sinkey Jr. 1988; Kanagaretnam et al. 2004) which indicates that bank managers largely use provisions for earnings management. Regarding the remaining three variables (TIER1, NINTINC, CASH), no significant deviations are reported. 


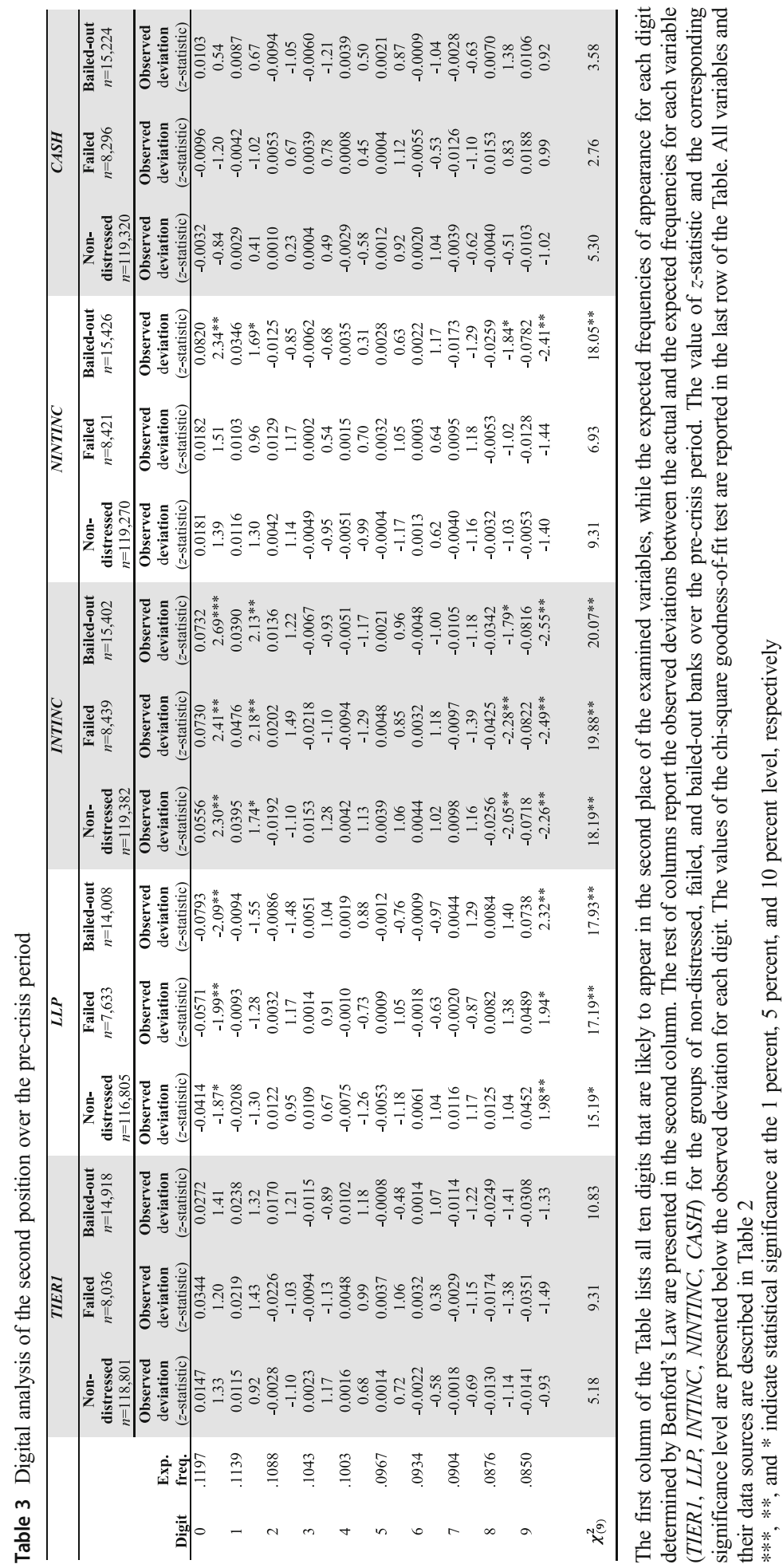




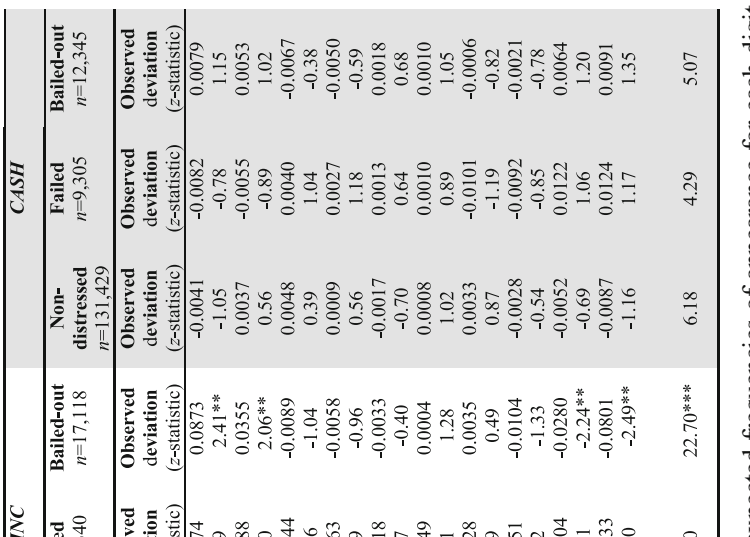

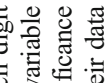

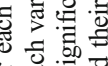

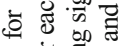

8 :

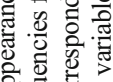

空 范

记焉要

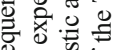

至焉

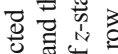

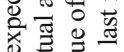

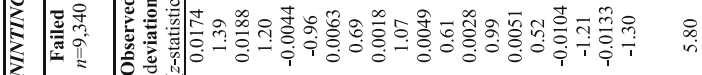

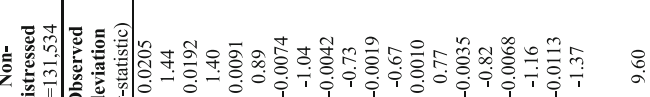

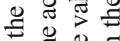

里 $\cong$

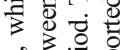

जै

. तै

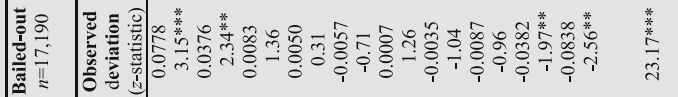

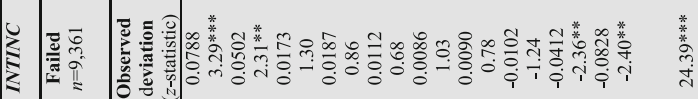

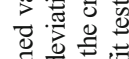

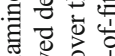

政

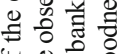

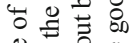

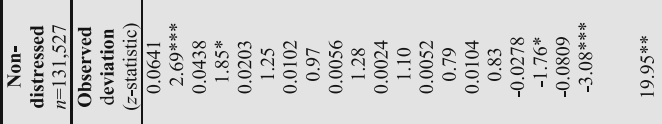

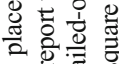

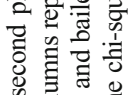

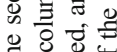

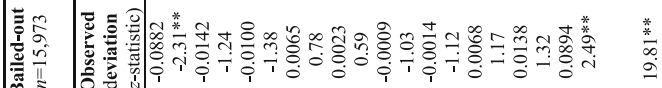

$\overrightarrow{8}$

Э

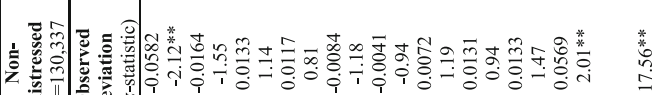

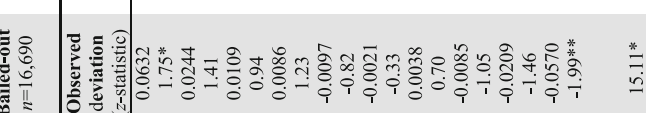

₹ च

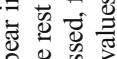

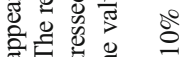

열 旁

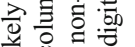

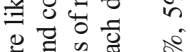

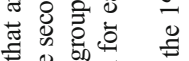

虽

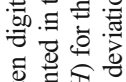

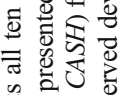

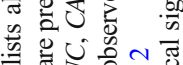

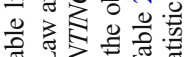

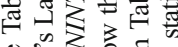

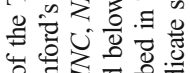

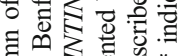

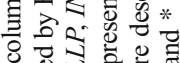

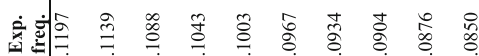

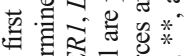

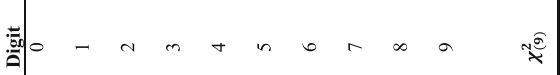

$\frac{2}{\frac{0}{2}}$

| 


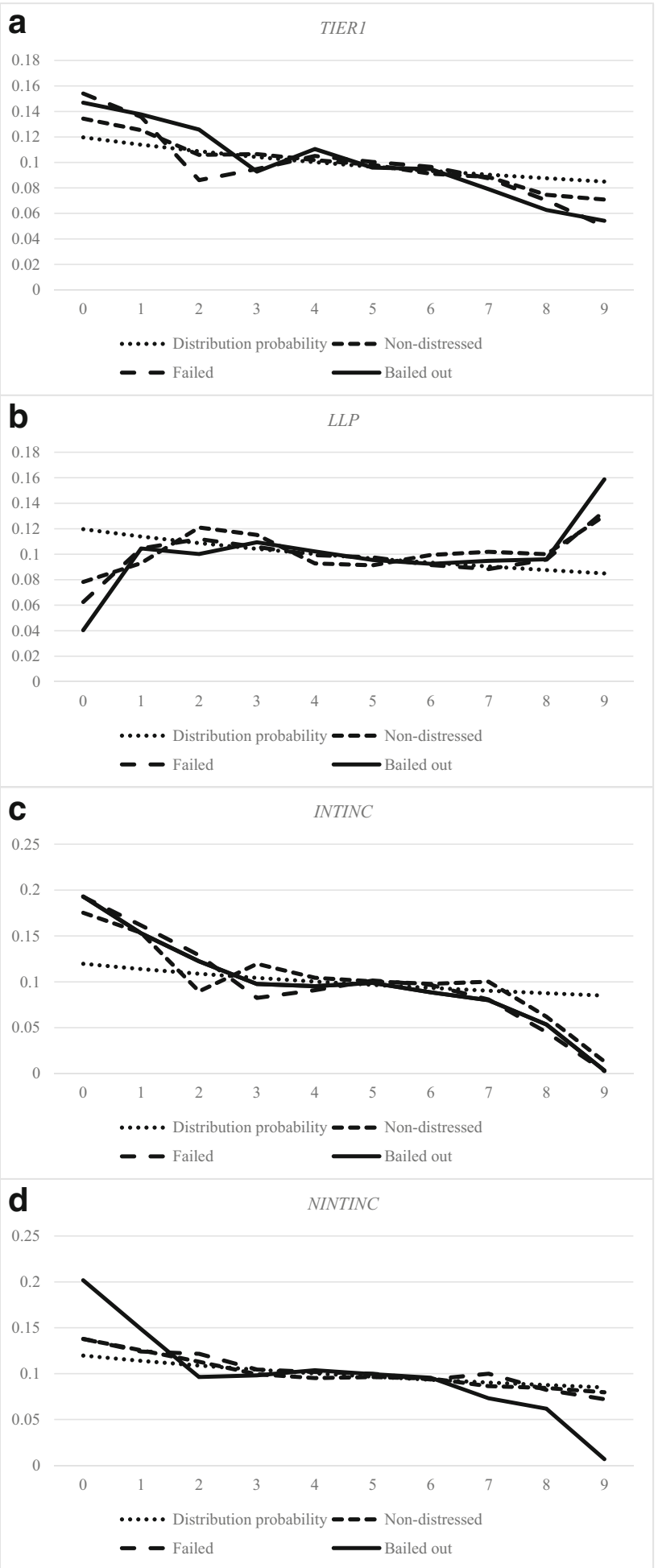


Fig. 2 Graphical representation of the results of digital analysis in the pre-crisis period. Panels A, B, C, and D provide graphical representations of the results of digital analysis for the second position in the manipulated accounting variables (TIERI, LLP, INTINC, and NINTINC, respectively) in the pre-crisis period. The values on the vertical axis are the distribution probabilities of digit $i(i=0,1,2, \ldots, 9)$ as shown on the horizontal axis

Results reveal the occurrence of large positive (negative) and significant proportional deviations in digits zero and one (eight and nine) of INTINC for failed banks. Deviations are larger in magnitude and more statistically significant if compared to the deviations observed for the non-distressed banks as shown in Table 5 (Panel C) that presents the significance tests of the deviations for digit 0 among the three types of banks across the two time periods based on $z$-statistic. ${ }^{8}$ Moreover, a downward bias is reported in LLP as Fig. 2 (Panel B) displays. This means that banks which later filed for bankruptcy appeared to be systematically manipulating $L L P$ downwards in the years prior to the crisis. The deviations in $L L P$ are both numerically larger and statistically significant compared to those reported for the non-distressed banks as Table 5 (Panel B) demonstrates. The upward manipulation of INTINC as well as the downward manipulation of $L L P$ are both confirmed by the results of the chi-square test. Any discrepancies between the actual and the expected frequencies for the remaining three variables (TIER1, NINTINC, $C A S H)$ for failed banks are not significant like for their non-distressed peers.

Possible upward data manipulation of interest income is also documented for the group of bailed-out banks. The actual proportion of zeros appearing in the second position of INTINC exceeds the expected proportion by $7.32 \%$, and the actual proportion of ones exceeds the expected proportion by $3.90 \%$. Deviations are significant at the $1 \%$ and $5 \%$ levels, respectively. As regards eights and nines, these are linked to actual proportions which are significantly lower from the anticipated proportions. Interestingly, bailed-out banks are found to manipulate non-interest income (NINTINC) upwards and loan loss provisions (LLP) downwards as shown in Fig. 2 (Panels B and D, respectively). A goodness-of-fit test produces significant results for all three manipulated variables (INTINC, NINTINC, LLP). Importantly, deviations in $L L P$ and INTINC are both numerically larger and statistically different compared to those reported for non-distressed banks as Table 5 (Panels $\mathrm{B}$ and $\mathrm{C}$, respectively) demonstrates.

\subsection{The Crisis Period}

Table 4 reports evidence of a strong upward data manipulation in interest income for all three groups of banks. The manipulation levels of INTINC are higher compared to those documented prior to the crisis: the incidence of zeros and ones in the second position of INTINC increased during the crisis, and, at the same time, the occurrence of eights and nines is lowered. The chi-square test provides significant results either at 1 or $5 \%$ levels for INTINC across the three groups of banks. Distressed (failed and bailed-out) banks manipulate INTINC to a greater extent compared to their non-distressed counterparts, similar to the pre-crisis period. The relevant differences are significant at the 5\% level as displayed in Table 5 (Panel C). In addition, bailed-out institutions exert an upward manipulative influence on non-interest income (NINTINC) as in the pre-crisis era. The chi-square test is significant at the $1 \%$ level, which suggests the rejection of the null of Benford's distribution.

\footnotetext{
${ }^{8}$ We also test the statistical significance of the reported deviations for digit 9 . The results we obtain which are very similar to those obtained for digit 0 are available upon request.
} 
Panel A: TIERI

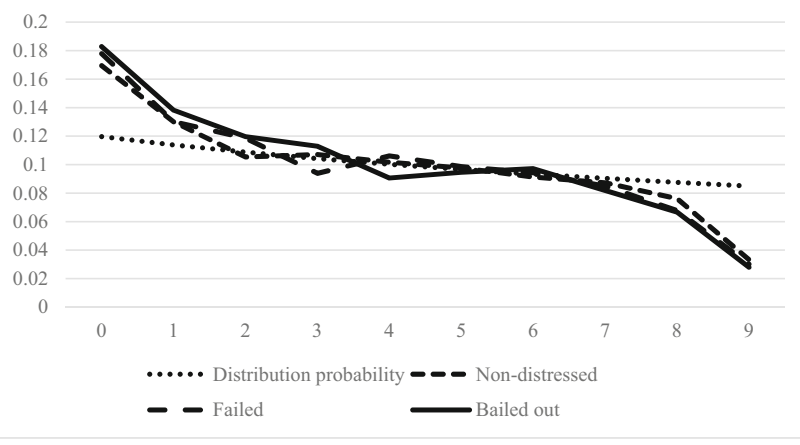

Panel B: $L L P$

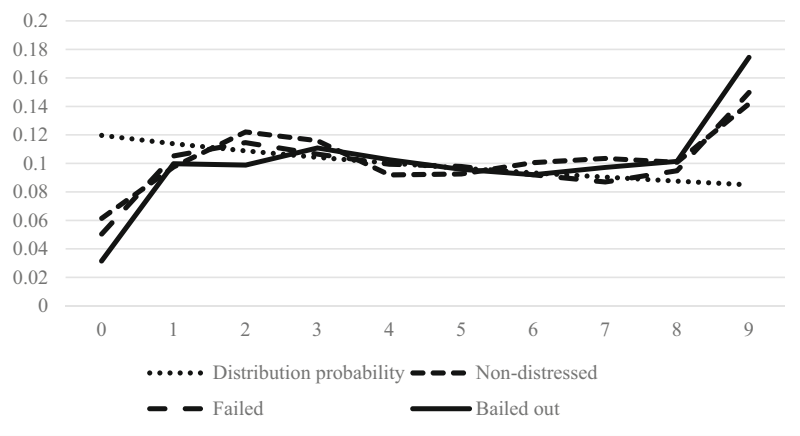

Panel C: INTINC

0.25

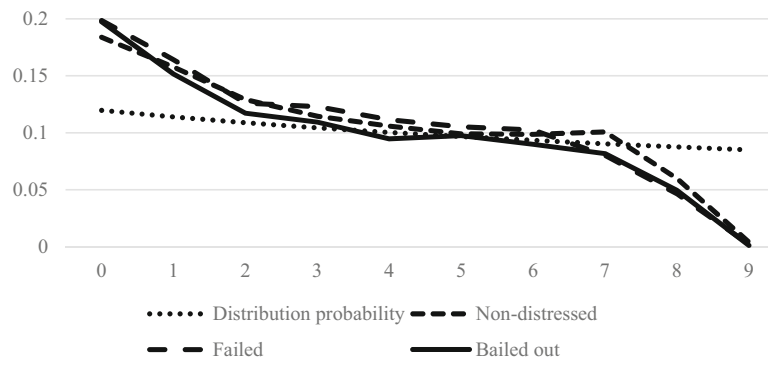

Panel D: NINTINC

0.25

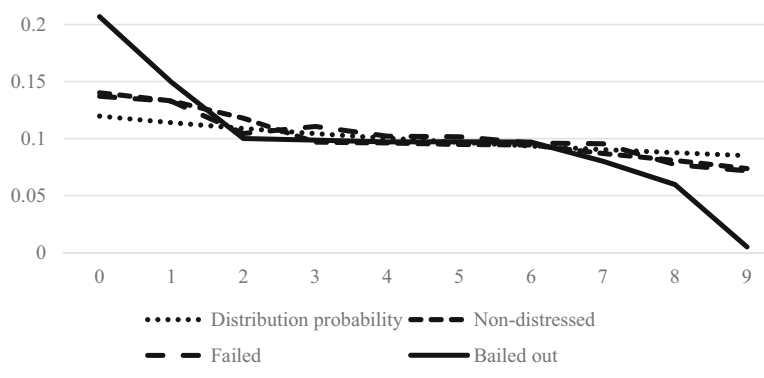


Fig. 3 Graphical representation of the results of digital analysis in the crisis period. Panels A, B, C, and D provide graphical representations of the results of digital analysis for the second position in the manipulated accounting variables (TIER1, LLP, INTINC, and NINTINC, respectively) in the crisis period. The values on the vertical axis are the distribution probabilities of digit $i(i=0,1,2, \ldots, 9)$ as shown on the horizontal axis

As regards the quality of bank assets, the values of $z$-statistic in Table 4 reveal significantly negative deviations in digit zero and significantly positive deviations in digit nine for loan loss provisions $(L L P)$ for all three groups of banks. The overall level of downward manipulation is significantly different for the two groups of distressed banks compared to their non-distressed counterparts (see Table 5, Panel B).

Remarkably, an excess of zeros and a shortage of nines in the second position of TIER 1 is reported for all three groups of banks. This constitutes a strong indication for upward data manipulation of regulatory capital as demonstrated in Fig. 3 (Panel A). The chi-square test confirms the statistical validity of all relevant deviations. Notably, the deviations between the distressed and the non-distressed (i.e., failed and bailed-out) banks are significant at 5\%, whereas those between the failed and bailed-out banks are not significant (Table 5, Panel A). Accordingly, banks, and especially the distressed ones, appear to act in accordance with Tilden and Janes (2012)'s findings of increased financial statement manipulation during recessionary times. Banks manipulate regulatory capital upwards by holding back on loan loss provisioning. Such a strategic behaviour, which is in line with the findings of Huizinga and Laeven (2012), enables banks with impaired assets to satisfy capital requirements even though their true health is problematic.

\subsection{Across the Two Periods}

All banks utilise loan loss provisions throughout the two periods to manipulate interest income upwards. In the case of bailed-out banks, the majority of which are large and universal institutions with a broad range of financial activities, non-interest income is also found to have been manipulated upwards in both periods. ${ }^{9}$ Banks' performance-based remuneration practices are widely considered to create strong managerial incentives to manipulate income. We provide solid evidence that data manipulation is more prevalent in distressed banks across the two periods. Weak banks tend to manage interest and non-interest income upwards by delaying loan loss provisions (Liu and Ryan 2006). Although distressed banks may be more closely monitored by regulators, they may be more desperate in reporting performance standards necessary for their survival.

Manipulation in asset quality (LLP) and interest income (INTINC) is both numerically larger in the crisis period and statistically higher compared to the pre-crisis period (Table 5, Panels B and C, respectively). Similarly, the manipulation in NINTINC that we document for bailed-out banks in the crisis period is stronger compared to that reported in the pre-crisis period; the relevant difference is significant at 5\% (Table 5, Panel D). Importantly, manipulation is expanded to affect regulatory capital. The reported differences in TIERl between the two periods are highly significant for all banks (Table 5, Panel A). Since the prospect of government bailouts creates incentives for

\footnotetext{
${ }^{9}$ Non-interest-based activities are formally defined by the Gramm-Leach-Bliley Act of 1999 and include securities dealing and underwriting, financial and investment advisory services, merchant banking, derivatives trading, issuing or selling securitised interests in bank-eligible assets, etc.
} 
Table 5 Statistical significance of the reported deviations from Benford's Law for digit zero

\begin{tabular}{|c|c|c|c|}
\hline Panel A: TIERI & $\begin{array}{l}\text { Pre-crisis } \\
\text { period }\end{array}$ & $\begin{array}{l}\text { Crisis } \\
\text { period }\end{array}$ & $\begin{array}{c}\text { Pre-crisis vs Crisis } \\
\text { (z-statistic) }\end{array}$ \\
\hline Non-distressed banks & 0.0147 & 0.0498 & $1.98 * *$ \\
\hline Failed banks & 0.0344 & 0.0582 & $2.60 * * *$ \\
\hline Bailed-out banks & 0.0272 & 0.0632 & $2.91 * * *$ \\
\hline $\begin{array}{c}\text { Non-distressed vs Failed banks } \\
\text { (z-statistic) }\end{array}$ & 1.24 & $2.02 * *$ & \\
\hline $\begin{array}{c}\text { Non-distressed vs Bailed-out banks } \\
\text { (z-statistic) }\end{array}$ & 1.06 & $2.33 * *$ & \\
\hline $\begin{array}{c}\text { Failed vs Bailed-out banks } \\
\text { (z-statistic) }\end{array}$ & 0.87 & 1.14 & \\
\hline Panel B: LLP & $\begin{array}{l}\text { Pre-crisis } \\
\text { period }\end{array}$ & $\begin{array}{l}\text { Crisis } \\
\text { period }\end{array}$ & $\begin{array}{c}\text { Pre-crisis vs Crisis } \\
\text { (z-statistic) }\end{array}$ \\
\hline Non-distressed banks & -0.0414 & -0.0582 & $-2.05 * *$ \\
\hline Failed banks & -0.0571 & -0.0692 & $-2.31 * *$ \\
\hline Bailed-out banks & -0.0793 & -0.0882 & $-2.88 * * *$ \\
\hline $\begin{array}{c}\text { Non-distressed vs Failed banks } \\
\text { (z-statistic) }\end{array}$ & $-1.99 * *$ & $-2.10 * *$ & \\
\hline $\begin{array}{l}\text { Non-distressed vs Bailed-out banks } \\
\text { (z-statistic) }\end{array}$ & $-2.24 * *$ & $-2.23 * *$ & \\
\hline $\begin{array}{c}\text { Failed vs Bailed-out banks } \\
\text { (z-statistic) }\end{array}$ & -0.90 & -0.82 & \\
\hline Panel C: INTINC & $\begin{array}{l}\text { Pre-crisis } \\
\text { period }\end{array}$ & $\begin{array}{l}\text { Crisis } \\
\text { period }\end{array}$ & $\begin{array}{c}\text { Pre-crisis vs Crisis } \\
\text { (z-statistic) }\end{array}$ \\
\hline Non-distressed banks & 0.0556 & 0.0641 & $2.19 * *$ \\
\hline Failed banks & 0.0730 & 0.0788 & $2.02 * *$ \\
\hline Bailed-out banks & 0.0732 & 0.0778 & $2.31 * *$ \\
\hline $\begin{array}{c}\text { Non-distressed vs Failed banks } \\
\text { (z-statistic) }\end{array}$ & $2.10 * *$ & $1.99 * *$ & \\
\hline $\begin{array}{l}\text { Non-distressed vs Bailed-out banks } \\
\text { (z-statistic) }\end{array}$ & $2.24 * *$ & $2.06 * *$ & \\
\hline $\begin{array}{c}\text { Failed vs Bailed-out banks } \\
\text { (z-statistic) }\end{array}$ & 1.38 & 1.40 & \\
\hline Panel D: NINTINC & $\begin{array}{l}\text { Pre-crisis } \\
\text { period }\end{array}$ & $\begin{array}{l}\text { Crisis } \\
\text { period }\end{array}$ & $\begin{array}{l}\text { Pre-crisis vs Crisis } \\
\text { (z-statistic) }\end{array}$ \\
\hline Non-distressed banks & 0.0281 & 0.0305 & 0.93 \\
\hline Failed banks & 0.0382 & 0.0274 & 1.05 \\
\hline Bailed-out banks & 0.0820 & 0.0873 & $2.09 * *$ \\
\hline $\begin{array}{c}\text { Non-distressed vs Failed banks } \\
\text { (z-statistic) }\end{array}$ & 1.14 & 1.07 & \\
\hline $\begin{array}{c}\text { Non-distressed vs Bailed-out banks } \\
\text { (z-statistic) }\end{array}$ & $3.95 * * *$ & $4.11 * * *$ & \\
\hline $\begin{array}{l}\text { Failed vs Bailed-out banks } \\
\text { (z-statistic) }\end{array}$ & $2.44 * *$ & $2.70 * * *$ & \\
\hline
\end{tabular}

This Table presents the deviations from Benford's Law for digit zero among the three types of banks (non-distressed, failed, and bailed out banks) and across the two time periods for the four variables (TIER1, LLP, INTINC, NINTINC) which are found to be manipulated in our baseline analysis. The values of the relevant statistical significance tests based on z-statistic are also reported. All variables and their data sources are described in Table 2 $* * *, * *$, and * indicate statistical significance at the $1 \%, 5 \%$, and $10 \%$ level, respectively 
distressed banks to take excessive risks (Kane 2018), a crucial prerequisite to obtain TARP/CPP assistance after the outbreak of the crisis was that applicant banks had to prove that they were viable. Hence, banks were incentivised to show to Federal assessors, among others, higher income streams and cash flows than the actual ones.

\subsection{Patterns of Manipulation}

We now examine the patterns of manipulation by applying Benford's Law to the first position of each of the relevant variables, INTINC, NINTINC, LLP, and TIER1. The results for the precrisis period are presented in Table 6 and are very similar to those obtained for the crisis period. ${ }^{10}$ The actual proportion of ones which appear in the first position of INTINC and TIER 1 is higher than anticipated for all banks; eights and (mostly) nines, on the other hand, are observed less often than expected. The same pattern is detected for NINTINC for the bailed-out banks. As regards $L L P$, its actual proportion of ones is lower than anticipated for the three groups of banks, whereas that of nines is higher than expected. The aforementioned deviations are significant at the $1 \%$ and $5 \%$ significance levels based on $z$-statistic. A chi-square test is also significant at the same levels.

Our results demonstrate that the data manipulation pattern is common among the examined variables. The documented upward pattern suggests that when an accounting figure starts with either the digit eight or nine it is more likely to be rounded up to a figure which has a one as the first digit. To give an example, a regulatory capital of $\$ 894$ million is likely to be rounded up to $\$ 1.012$ billion. ${ }^{11}$ In the context of a downward manipulation, on the other hand, the reported pattern shows that banks tend to decrease the value of an accounting figure when its first digit is one to a figure which starts with the digit nine. For instance, loan loss provisions of $\$ 1.085$ million are manipulated downwards to $\$ 991,062$. Interestingly, neither the level of soundness of banks under scrutiny (i.e., distressed vs non-distressed banks), nor the occurrence of the crisis alter the documented pattern of manipulation.

Results, which are consistent with the results obtained by studies like Carslaw (1988), Thomas (1989), and Van Caneghem (2002) suggest that banks exercise manipulation to increase the magnitude of balance sheet (TIER1) and income statement variables (INTINC and NINTINC) when the level of these variables is slightly below a round number. By the same token, banks manipulate loan loss provisions downwards when their level is slightly above a round number. That is, banks utilise data manipulation to conceal their financial difficulties and present an artificially improved view of their performance to outsiders.

\section{Robustness Analysis}

We carry out a number of different tests to validate the robustness of our findings. We start by testing the sensitivity of our results to a set of alternative CAMELS components. The book equity capital (EQUITY) is used to measure capital adequacy; asset quality is measured by

\footnotetext{
${ }^{10}$ To save space, the Table that displays the results for the crisis period is presented in the Internet Appendix of this paper that can be found in: https:/npapanikolaou.wordpress.com/research/internet-appendix/

${ }^{11} \mathrm{Lin}$ and $\mathrm{Wu}$ (2014) provide evidence for rounding when seven is at the first position, which reveals a more gripping manipulation pattern.
} 


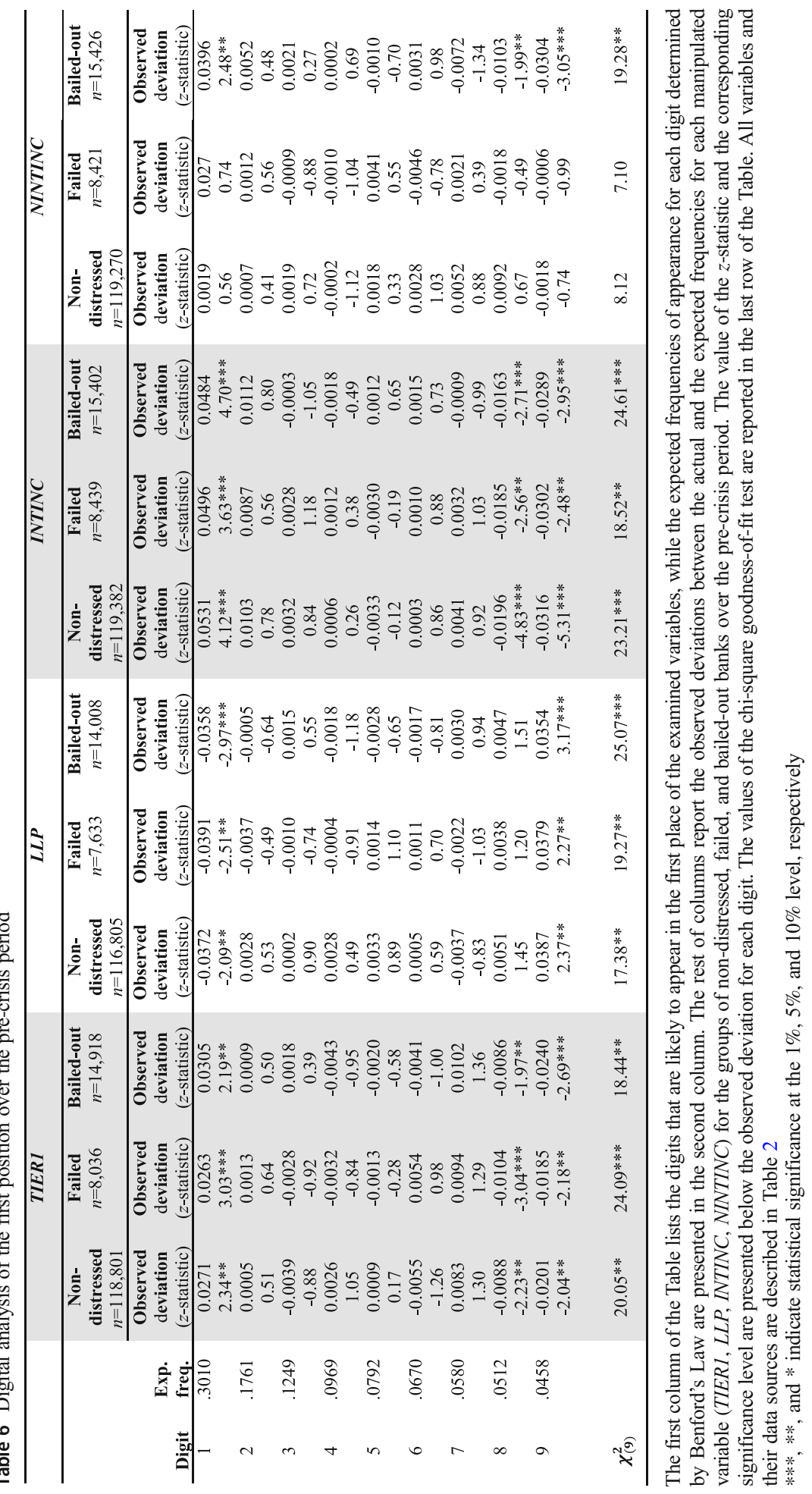


non-performing loans (NPL) and by allowances for loan losses (ALLOW); earnings strength is based on total earning assets (EARNAS); and liquidity is captured by federal funds purchased and securities sold under agreements to repurchase (REPOS). Variables and data sources are described in Table 2.

The results for the pre-crisis period in Table 7 reveal the occurrence of positive (negative) and significant proportional deviations in digits zero and one (eight and nine) for $E A R N A S$ across the three groups of banks. A downward bias is reported in $A L L O W$ for the groups of distressed banks as there are more nines and fewer zeros than anticipated in the second digit; deviations are significant at the $5 \%$ level. The goodness-of-fit chi-square test produces significant results for both EARNAS and ALLOW. No indication of manipulation is found for bank capital (EQUITY) and liquidity $(R E P O S)$ in the pre-crisis period, which corroborates our baseline results.

To the extent that loan loss allowances are included in the regulatory capital of banks, managers have incentives to manipulate $A L L O W$ downwards with the purpose of demonstrating that a strong capital cushion has been set aside to absorb shocks in a financial turmoil. Under the Financial Accounting Standards No. 5 (FASB 1975) entitled 'Accounting for Contingencies', when credit losses are likely and can be reasonably estimated, an expense called loan loss provisions and a contra-asset (to earning assets outstanding) called loan loss allowances should be recorded on banks' accounting books. That is, by manipulating loan loss provisions downwards as documented in our baseline analysis, banks are inclined to follow the same or similar strategies with loan loss allowances, and, by doing so, are entitled to artificially increase the volume of earning assets.

Turning to the crisis period, the results in Table 8 reveal an upward manipulation of $E A R N A S$ for all three groups of banks; manipulation is stronger compared to the pre-crisis period. Regarding asset quality, the values of $z$-statistic demonstrate significantly negative deviations in digit zero and significantly positive deviations in digit nine for both $A L L O W$ and $N P L$ for the two groups of distressed banks. The chi-square test confirms the statistical validity of these deviations. The downward manipulation in $N P L$ can be explained by the direct relation that holds between non-performing loans and loan loss provisions: higher levels of non-performing loans imply troubles in the loan portfolio of banks and these troubles are normally reflected in higher loss provisions as documented in our baseline analysis (Kanagaretnam et al. 2010). Interestingly, we find no indication of manipulation in EQUITY. This means that banks are mainly interested in appearing to be sufficiently capitalised by solely manipulating their regulatory capital (TIER1) upwards. Lastly, by applying Benford's Law to the first position of EARNAS, ALLOW, and NPL, we can corroborate the rather unnoticeable manipulation patterns detected in our baseline analysis.

As an additional robustness test, we consider Nigrini (1996)'s Distortion Factor (DF) model that indicates whether data are overstated or understated and that also estimates the extent of manipulation. The DF model compares the mean of the actual numbers in a data set and the mean of the expected numbers based on Benford's Law. Since there is no unique mean for the numbers contained in a data set which closely approximates the Law because such a data set consists of relatively large or small numbers, Nigrini (1996) suggests moving the decimal point of each actual number so that each number would fall into the interval $[10,100)$. More concretely, each number that is below 10 is expanded to a number within the range $[10,100)$. Similarly, each number that is larger than 100 is 


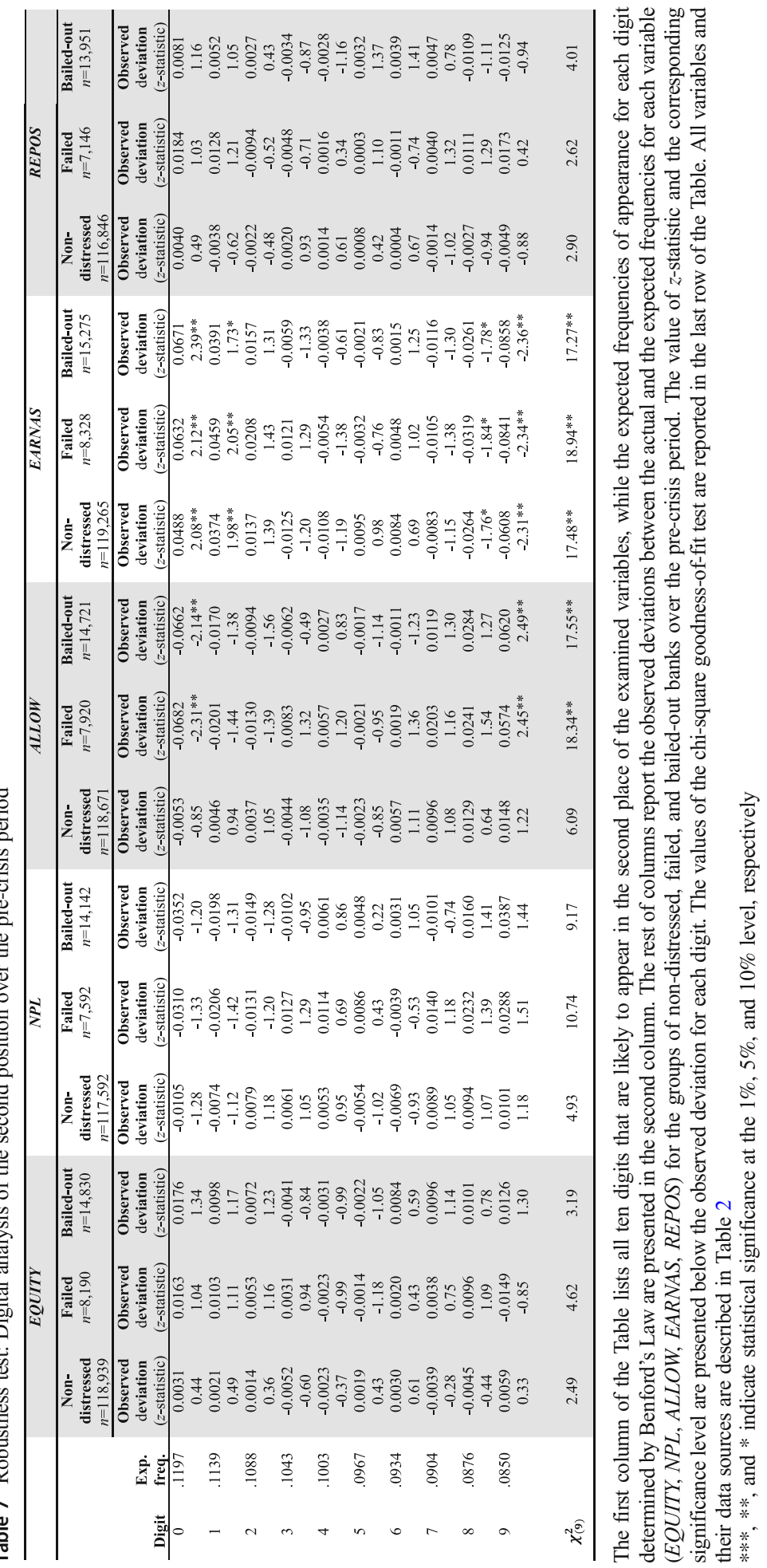




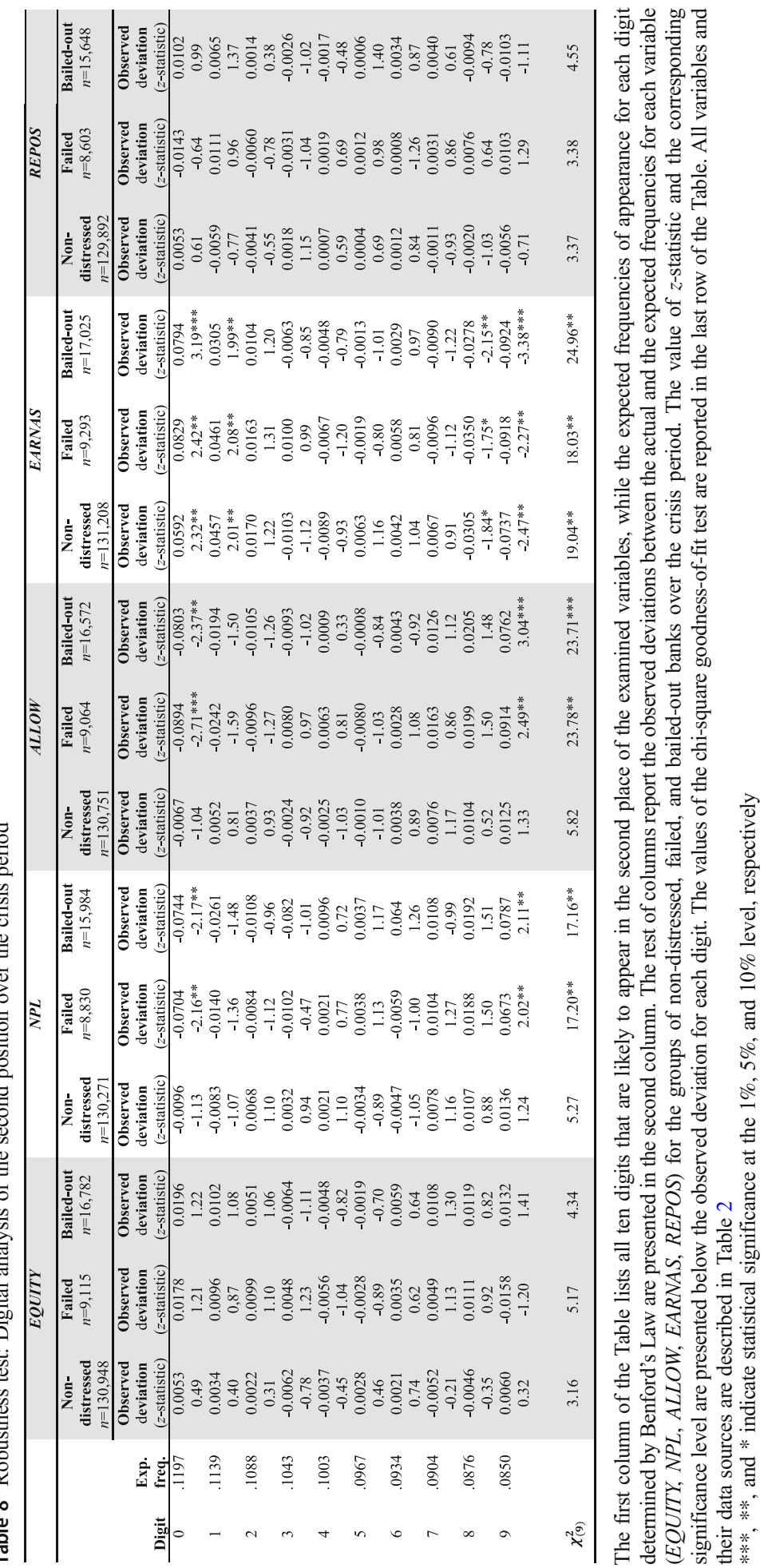


collapsed to a number within the range $[10,100)$. For example, the number 4.29 expands to 42.9, while the number 1040 collapses to 10.4 . A comparison is then made between the mean of the set of actual numbers scaled to the $[10,100)$ range and the mean of the set of the expected numbers that conform to the Law.

The Actual Mean $(A M)$ of the $n$ collapsed or expanded data is:

$$
A M=\frac{\sum X}{n},
$$

where $X$ stands for the collapsed or the expanded data values, and $n$ is the number of observations of the examined variable. The Expected Mean $(E M)$ of Benford's distribution is:

$$
E M=\frac{90}{n\left(10^{\frac{1}{n}}-1\right)}
$$

We can now calculate $D F$ as follows:

$$
D F=\frac{(A M-E M) 100}{E M}
$$

Equation (8) reflects the average percentage manipulation of the examined data. When $D F$ is positive (negative), an upward (downward) manipulation is detected. Since $A M$ and $E M$ are the means of $n$ random variables, the distribution of $D F$ approaches the normal distribution according to the central limit theorem. Hence, the $z$-statistic that tests the null hypothesis that the $A M$ equals the $E M$ can be computed for a relatively large $n .^{12}$

To enhance the validity of this robustness test, we account for possible selection bias in our sample of banks. Therefore, we exclude the distressed banks that were not expected to be let to fail as there were systemically important. The managers of those banks had, in principle, little incentives to resort to manipulation. On the same day that the U.S. Treasury launched TARP/CPP, nine of the largest banks which together accounted for approximately $55 \%$ of the U.S. banks' assets were 'arm twisted' by authorities to participate in the programme. Those banks were: Bank of America, Citigroup, JP Morgan Chase, Wells Fargo, Morgan Stanley, Goldman Sachs, Bank of New York Mellon, State Street, and Merrill Lynch. We also exclude Washington Mutual since its largest subsidiary was a thrift institution and not a commercial or a savings bank. By excluding these banks from our sample, we remove the impact of extreme values and outliers that may have an effect on the observed frequencies and the relevant digital analysis.

Table 9 presents the $D F$ values in percentage terms for all ten variables under scrutiny for the three groups of banks over the two periods. The reported signs and the magnitude of $D F$ confirm the results obtained in our baseline analysis. Total earning assets (EARNAS) are significantly distorted upwards by $7.41 \%, 6.93 \%$, and $6.53 \%$ for the non-distressed, failed, and bailed-out banks respectively in the pre-crisis period. The relevant percentages in the crisis years are equal to $7.82,9.30$, and 8.81 for the three banking groups, respectively. A very similar distortion pattern is documented for total interest income (INTINC). Furthermore, a significant upward distortion of $7.42 \%$ in the pre-crisis period and $8.94 \%$ in the crisis period is documented for the non-interest income (NINTINC) of bailed-out banks, which is also in line

$\overline{12}$ To calculate $z$-statistic, we obtain the standard deviation of $D F$ by following the computations found in Nigrini (1996)`s Appendix A. 


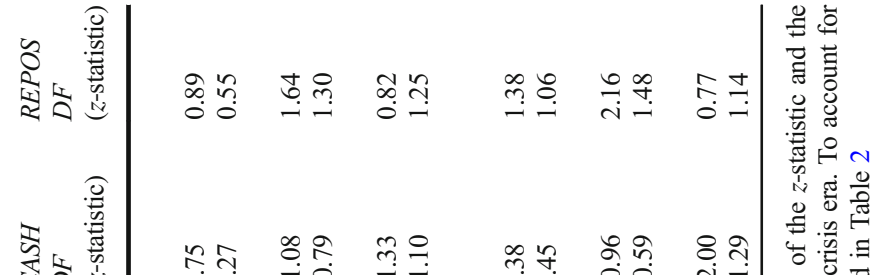

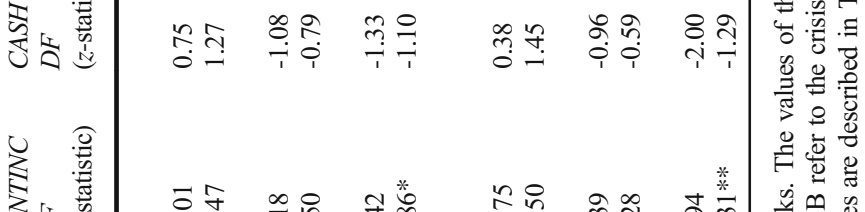

之地跑

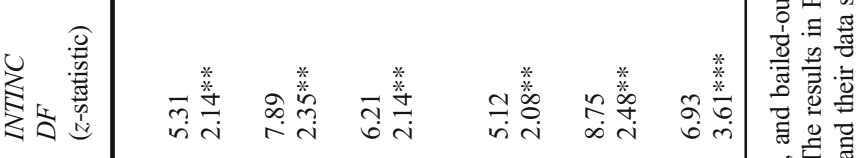

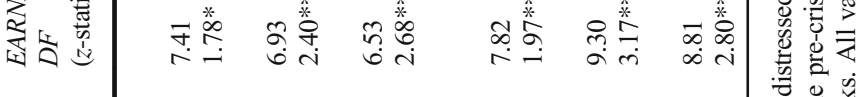

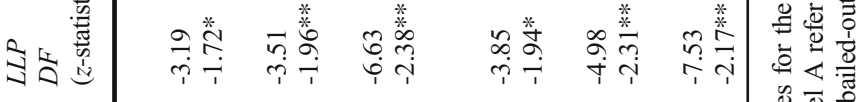

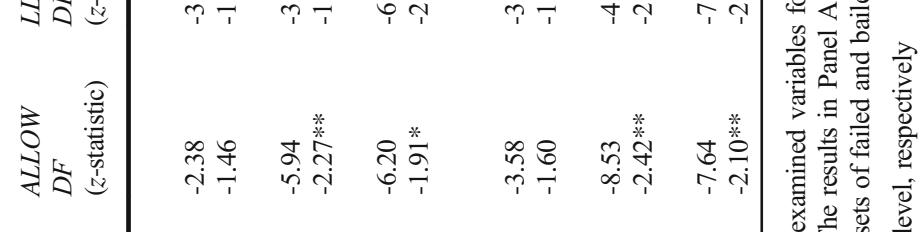

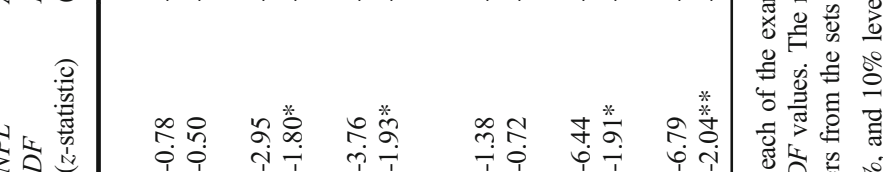

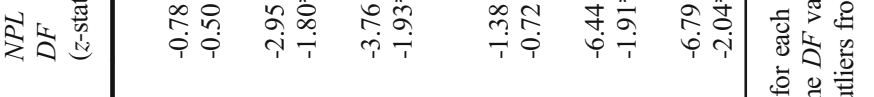

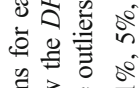

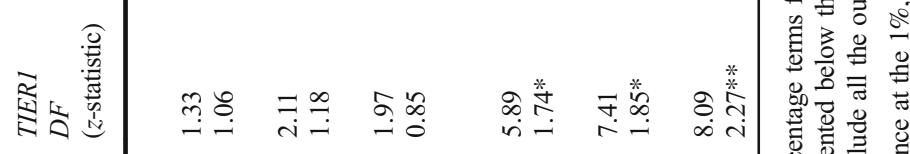

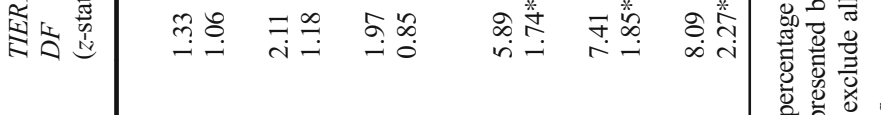

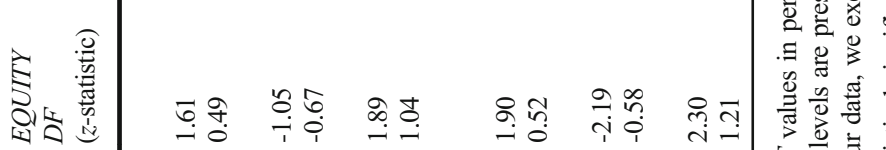

造遂

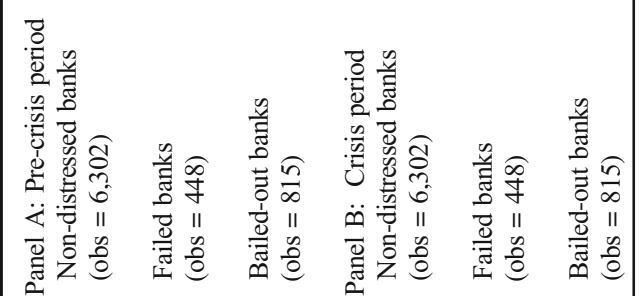

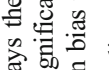


with our baseline findings. We further confirm that manipulation is magnified and expanded after the outbreak of the crisis. ${ }^{13}$ All banks are found to be involved in an upward manipulation of the core regulatory capital during the crisis period. Indeed, TIER1 is significantly manipulated upwards, where the extent of manipulation is higher for the distressed institutions. Moreover, loan loss allowances $(A L L O W)$ are significantly distorted downwards by failed and bailed-out banks in the pre-crisis period $(-5.94 \%$ and $-6.20 \%$, respectively). The magnitude of distortion is enhanced in the crisis period $(-8.53 \%$ and $-7.64 \%$, respectively). Loan loss provisions $(L L P)$ are also found to be distorted downwards by all banks across the two time periods. The reported distortion is significant at the $5 \%$ level and is stronger in the crisis period. As regards non-performing loans $(N P L)$, these are manipulated downwards by the set of distressed banks not only in the crisis period (as evidenced the baseline analysis), but also in the pre-crisis period.

To further enhance the robustness of our results, we confirm the validity of the crisis effect and that of the effect of distressed banks by carrying out two placebo tests. Lastly, the ability of Benford's Law to predict data manipulation is corroborated by an out-of-sample prediction analysis we conduct. ${ }^{14}$

\section{Conclusions}

Manipulation may transmit noise to the operation of the banking sector. It distorts the expectations of shareholders and other investors about the individual bank valuations and the overall financial conditions in the sector. It also misleads authorities in their task to identify and address any problems in the operation of banks and to unravel any sources of instability for the whole industry. We utilise Benford's Law to test whether and to what extent a set of fundamental balance sheet and income statement data were manipulated prior to and also after the crisis.

Several interesting findings are reported in our baseline analysis and are corroborated by robustness checks. Banks, regardless of their financial condition, appear to utilise loan loss provisions to manipulate earnings and interest income upwards throughout the two periods. For bailed-out banks, non-interest income, which is a key income component in their business model, is also manipulated upwards in both periods. Furthermore, distressed (bailed out and failed) banks resort to the downward manipulation of allowances for loan losses and nonperforming loans and this, in combination with the delay in loan loss provisions, enables them to artificially increase their reported earnings. As such, manipulation is more evident in distressed institutions. Moreover, manipulation is magnified in the crisis period for all the examined banks. It also encompasses regulatory capital.

In sum, banks' data manipulation decreases the reliability of accounting information, erodes confidence, and undermines their credibility. Manipulation yields a distorted view of the financial conditions and the health of banks, which may have the effect of increasing regulatory forbearance. It is, therefore, crucial for authorities and other outsiders to find ways to reduce manipulation. Our results call for a more in-depth evaluation of the quality of the

\footnotetext{
${ }^{13}$ We also use the collapse of Lehmann Brothers in $2008 \mathrm{q} 3$ as the starting point of the crisis. The results confirm the validity of the crisis effect.

${ }^{14}$ A detailed discussion of the placebo and the out-of-sample tests is presented in the Internet Appendix: https://npapanikolaou.wordpress.com/research/internet-appendix/
} 
bank accounting information by applying a Benford's Law-type analysis, which can assist authorities in deterring manipulation both under normal financial conditions, and during financial debacles when the phenomenon is exaggerated.

Acknowledgements We thank the Organising Committee of the 23rd MFS Conference 2016 for awarding Nikolaos I. Papanikolaou with the Best Young Researcher Award. We also thank the participants in the FMA European Meeting 2015 as well as the Scientific Committee members for nominating the paper for one of the two Best Paper Awards. Special thanks to the participants in the XXIV International Rome Conference on Money, Banking and Finance and to those in the Financial Intermediation Network of European Studies (FINEST) 2016 and 2018 Workshops for their valuable comments and suggestions. We are indebted to Nicola Cetorelli, Franco Fiordelisi, William (Bill) Megginson, Marco Pagano, and George Pennacchi for their insightful discussions, which helped us to improve the quality of our work. Furthermore, the paper has been benefited from comments by Olivier De Jonghe, Bill Francis, Claudio Giannotti, Dimitrios Gounopoulos, Iftekhar Hasan, Saverio Stentella Lopes, Phillip Molyneux, Daniele Angelo Previati, Kostas Tsatsaronis, Piet Usselmann, and Stefano Zedda. Also, we would like to thank Aineas Mallios and Mounir Shal for their assistance in data collection and refinement. We also thank the Faculty of Management of Bournemouth University for the provided financial support via the Mid-Career Seedcorn Funding scheme. Our sincere thanks to an anonymous reviewer of the Journal of Financial Services Research for their incisive comments. Special thanks are extended to Christopher Hartwell and Tim Lloyd for their professional assistance in proofreading the paper.

Open Access This article is licensed under a Creative Commons Attribution 4.0 International License, which permits use, sharing, adaptation, distribution and reproduction in any medium or format, as long as you give appropriate credit to the original author(s) and the source, provide a link to the Creative Commons licence, and indicate if changes were made. The images or other third party material in this article are included in the article's Creative Commons licence, unless indicated otherwise in a credit line to the material. If material is not included in the article's Creative Commons licence and your intended use is not permitted by statutory regulation or exceeds the permitted use, you will need to obtain permission directly from the copyright holder. To view a copy of this licence, visit http://creativecommons.org/licenses/by/4.0/.

\section{References}

Abrantes-Metz R, Villas-Boas S, Judge G (2011) Tracking the Libor rate. Appl Econ Lett 18:1-7

Ahmed AS, Takeda C, Thomas S (1999) Bank loan-loss provisions: a reexamination of capital management, earnings management, and signaling effects. J Account Econ 28:1-25

Alali FA, Romero S (2013) Benford's law: analyzing a decade of financial data. J Emerg Technol Account 10:1-39

Amiram D, Bozanic Z, Rouen E (2015) Financial statement errors: evidence from the distributional properties of financial statement numbers. Rev Acc Stud 20:1540-1593

Ashton JK, Hudson RS (2008) Interest rate clustering in UK financial services markets. J Bank Financ 32:1393-1403

Beatty A, Liao S (2014) Financial accounting in the banking industry: a review of the empirical literature. J Account Econ 58:339-383

Beatty A, Ke B, Petroni KR (2002) Earnings management to avoid earnings declines across publicly and privately held banks. Account Rev 77:547-570

Beneish MD (1999) The detection of earnings manipulation. Financ Anal J 55:24-36

Beneish MD, Lee MCC, Nichols DC (2013) Earnings manipulation and expected returns. Financ Anal J 69:57-82

Benford F (1938) The law of anomalous numbers. Proc Am Philos Soc 78:551-572

Brahler G, Engel S, Gottsche M, Rauch B (2011) Fact and fiction in EU-governmental economic data. Ger Econ Rev 12:243-255

Carslaw C (1988) Anomalies in the income numbers: evidence of goal oriented behavior. Account Rev 63:321-327

Cohen LJ, Cornett MM, Marcus AJ, Tehranian H (2014) Bank earnings management and tail risk during the financial crisis. J Money Credit Bank 46:171-197

Dechow PM, Dichev I (2002) The quality of accruals and earnings: the role of accrual estimation errors. Account Rev 77(supplement):35-59

Dechow PM, Sloan RG, Sweeney AP (1995) Detecting earnings management. Account Rev 70:193-225

Dechow PM, Ge W, Schrand CM (2010) Understanding earnings quality: a review of the proxies, their determinants, and their consequences. J Account Econ 50:344 401 
Dechow PM, Ge W, Larson CR, Sloan RG (2011) Predicting material accounting misstatements. Contemp Account Res 28:17-82

Dechow P, Hutton A, Kim JH, Sloan R (2012) Detecting earnings management: a new approach. J Account Res 50:275-334

Diamond DW (1984) Financial intermediation and delegated monitoring. Rev Econ Stud 51:393-414

Diekmann A (2007) Not the first digit! Using Benford's law to detect fraudulent scientific data. J Appl Stat 34: 321-329

Duchin R, Sosyura D (2012) The politics of government investment. J Financ Econ 106:24 48

Durtschi C, Hillison W, Pacini C (2004) The effective use of Benford's law to assist in detecting fraud in accounting data. J Forensic Account 5:17-34

Flannery M, Kwan SH, Nimalendran M (2013) The 2007-2009 financial crisis and bank opaqueness. J Financ Intermed 22:55-84

Gonzales-Garcia J, and G Pastor 2009 Benford's law and macroeconomic data quality. Working Paper 09/10, International Monetary Fund

Greenawalt MB, Sinkey JF Jr (1988) Bank loan-loss provisions and the income-smoothing hypothesis: an empirical analysis, 1976-1984. J Financ Serv Res 1:301-318

Hales D, Sridharan V, Radhakrishnan A, Chakravorty S, Samia S (2008) Testing the accuracy of employeereported data: an inexpensive alternative approach to traditional methods. Eur J Oper Res 189:583-593

Healy PM (1985) The effect of bonus schemes on accounting decisions. J Account Econ 7:85-107

Hribar P, Collins DW (2002) Errors in estimating accruals: implications for empirical research. J Account Res 40: $105-134$

Huizinga H, Laeven L (2012) Bank valuation and accounting discretion during a financial crisis. J Financ Econ 106:614-634

Jensen M, Meckling W (1976) Theory of the firm: managerial behavior, agency costs, and capital structure. J Financ Econ 4:177-203

Jones J (1991) Earnings management during import relief investigations. J Account Res 29:193-228

Judge G, Schechter L (2009) Detecting problems in survey data using Benford's law. J Hum Resour 44:1-24

Kanagaretnam K, Lobo GJ, Yang D (2004) Joint tests of signaling and income smoothing through bank loan loss provisions. Contemp Account Res 21:843-884

Kanagaretnam K, Krishnan GV, Lobo GJ (2010) An empirical analysis of auditor independence in the banking industry. Account Rev 85:2011-2046

Kane EJ (2018) Ethics versus ethos in US and UK megabanking. J Financ Serv Res 53:211-226

Kothari SP, Leone AJ, Wasley CE (2005) Performance matched discretionary accrual measures. J Account Econ 39:163-197

Laeven L (2013) Corporate governance: What's special about banks? Annu Rev Financ Econ 5:63-92

Lin F, Wu S-F (2014) Comparison of cosmetic earnings management for the developed markets and emerging markets: some empirical evidence from the United States and Taiwan. Econ Model 36:466-473

Lin F, Lin L-J, Yeh C-C, Wang T-S (2018) Does the board of directors as fat cats exert more earnings management? Evidence from Benford's law. Q Rev Econ Financ 68:158-170

Liu C-C, Ryan SG (2006) Income smoothing over the business cycle: changes in banks' coordinated management of provisions for loan losses and loan charge-offs from the pre-1990 bust to the 1990 boom. Account Rev 81:421-441

McNichols MF (2000) Research design issues in earnings management studies. J Account Public Policy 19:313345

Michalski T, Stoltz G (2012) Do countries falsify economic data strategically? Some evidence that they might. Rev Econ Stat 94:1-83

Morgan D (2002) Rating banks: risk and uncertainty in an opaque industry. Am Econ Rev 92:874-888

Newcomb S (1881) Note on the frequency of use of the different digits in natural numbers. Am J Math 4:39-40

Nigrini MJ (1996) A taxpayer compliance application of Benford's law. J Am Tax Assoc 18:72-91

Nigrini MJ 2012 Benford's law: applications for forensic accounting, Auditing and Fraud Detection, Wiley

Nigrini MJ, Mittermaier LJ (1997) The use of Benford's law as an aid in analytical procedures. Audit J Pract Theory 16:52-67

Niskanen J, Keloharju M (2000) Earnings cosmetics in a tax-driven accounting environment: evidence from Finnish public firms. Eur Account Rev 9:443-452

Nye J, Moul C (2007) The political economy of numbers: on the application of Benford's law to international macroeconomics statistics. B.E. J Macroecon 7:1-12

Securities and Exchange Commission (SEC) 2013 Accounting and auditing enforcement, release no. 3514/ December 4. Washington: SEC

Securities and Exchange Commission (SEC) 2014 Accounting and auditing enforcement, release no. 3588/ September 29. Washington: SEC 
Securities and Exchange Commission (SEC) 2015 Accounting and auditing enforcement, release no. 3622/ January 28. Washington: SEC

Skousen C, Guean L, Wetzel S (2004) Anomalies and unusual patterns in reported earnings: Japanese managers round earnings. J Int Financ Manag Acc 15:212-234

Stojanovic D, Vaughan MD, Yeager TJ (2008) Do Federal home loan bank membership and advances increase bank risk-taking? J Bank Financ 32:680-698

Thomas JK (1989) Unusual patterns in reported earnings. Account Rev 64:773-787

Tilden C, Janes T (2012) Empirical evidence of financial statement manipulation during economic recessions. J Financ Account 10:1-15

Van Caneghem T (2002) Earnings management induced by cognitive reference points. Br Account Rev 34:167178

Vyas D (2011) The timeliness of accounting write-downs by U.S. financial institutions during the financial crisis of 2007-2008. J Account Res 49:823-860

Publisher's Note Springer Nature remains neutral with regard to jurisdictional claims in published maps and institutional affiliations. 